American Journal of Infectious Diseases 3 (1): 36-41, 2007

ISSN 1553-6203

(C) 2007 Science Publications

\title{
Leprosy Patients Attending the Out Patient's Clinic at Agra: A Retrospective Analysis of the Characteristics and Frequency of Regularity VS Irregularity for Determining Absenteeism, Non-adherence and Non-compliance
}

\author{
Virendra S. Yadav, Kiran Katoch and Tahziba Hussain \\ Division of Biostatistics, National JALMA Institute for Leprosy and Other Mycobacterial Diseases \\ (Indian Council of Medical Research), Tajganj, Agra-282001. India
}

\begin{abstract}
This study reports a retrospective analysis of the records of 2709 leprosy patients, attending the Out patient's Clinic at Agra, over a 1-year period, 2005. The patients with leprosy have been categorized into three groups, viz., regular, irregular and the drop-outs. The number of drop-out patients was significantly higher $[\mathrm{Z}=2.16, \mathrm{p}=0.05]$ among males, 32.14\% (667) when compared with females, $26.50 \%$ (168). Religion was not observed to be a significant determinant in the regularity, irregularity and/or drop-out among the patients but the locality/residential background seemed to play a key role in Clinic attendance. Patients from urban areas were less regular 38.9\% (218) and the number of irregulars and drop-outs were more, i.e., $24.1 \%$ (135) and 37\% (207), respectively when compared with the patients from rural areas $\left[\mathrm{X}^{2}=14.894, \mathrm{p}=0.00006\right]$. Pauci-bacillary or multibacillary type of leprosy did not appear to be a significant determinant in the regularity, irregularity and / or drop-out among the patients. With regard to the various professions, the number of irregulars and drop-outs among patients engaged in some kind of business seemed to be more. The patients in whom the disease had become inactive, 69.7\% (60) seemed to be more regular in clinic attendance than the patients with active leprosy disease. The irregularity and drop-out rate was significantly less $\left[\mathrm{X}^{2}=5.107, \mathrm{p}=0.078\right]$. In all, $1226(45.26 \%)$ patients were found to be regular in clinic attendance but $648(23.92 \%)$ patients were irregular and $835(30.83 \%)$ patients were dropouts. The present study looked at the characteristics and factors responsible for irregular attendance of a large number of patients over a 1-year period, even after 50 years of implementation of the Leprosy Control/elimination programmes. This study is the first of its kind in Northern India.
\end{abstract}

Key words: Leprosy patients, OPD attendance, irregularity, non-adherence, non-compliance

\section{INTRODUCTION}

India has the largest number of known cases of leprosy and northern region incidentally happens to be endemic for the disease. WHO lists leprosy as one of the major health problems of developing countries including India, Brazil, Africa, Nepal and Bangladesh ${ }^{[1-}$

3]. Leprosy is a chronic disease associated with deformity in some cases, which has given rise to the social stigma and ostracizing of patient from society. The Government of India launched the National Leprosy Elimination Program (NLEP) in 1952-54 with the aims of eliminating leprosy through early detection of cases by population survey, contact screening/examination and voluntary referral by the year $2000 \mathrm{AD}^{[4]}$. To achieve the goals of NLEP, it is necessary to treat all leprosy patients so that transmission of the disease can be stopped. This Institute, originally named JALMA (Japanese Leprosy Mission for Asia) was started by the Japanese people, way back in 1962 for the treatment, care, support and management of leprosy patients. It was subsequently handed over to the Government of India in 1963. This Institute caters to the needs of a large number of leprosy patients in the northern region of India. Every year, around 5,000 patients attend the Out patient's Clinic. The patients are given free treatment after diagnosis of the disease, monitored and followed-up carefully. In order to help the patients and reduce the burden of travel and expenses, they are even provided $75 \%$ concessional pass to travel by Railways. Physiotherapy and surgery are also provided to complicated cases.

In the present study, a retrospective analysis of the records of 2709 leprosy patients, attending the Unit-1 of

Corresponding Author: Tahziba Hussain, Ph. D., HIV/AIDS Unit, National Jalma Institute for Leprosy and Other Mycobacterial Diseases (Indian Council of Medical Research), Tajganj, Agra - 282001, India Tel: +91-0562-2331751-4.ext.287, FAX: +91-0562-2331755 
Out patient's Clinic at Agra, over a 1-year period, 2005 were carried out to study the characteristics and factors responsible for absenteeism, non-adherence and noncompliance. This would provide an insight into the actual situation in this region of the country even after 50 years of the implementation of NLEP.

\section{MATERIALS AND METHODS}

Study design: In the present study, data was collected from the record files of the Unit-1 of the Out patient's Clinic (OPD) of National JALMA Institute for Leprosy $\&$ other Mycobacterial Diseases, Agra over a 1-year period, 2005 and analysed for regularity, irregularity and drop-out rates among the leprosy patients.

Inclusion criteria: A total of 2709 patients were included in the study. The Clinicians made the diagnosis of active leprosy disease based on the signs, symptoms, clinical and bacteriological findings. The socio-demographic data namely, age, gender, residential background (rural vs urban), occupation/profession, religion, type of disease, status of initial infection/disease and history of earlier treatment etc., were recorded. Leprosy patients came from rural and urban areas from different districts of Uttar Pradesh like (Barielly, Chandosi, Farrukhabad, Haldwani, Hathras, Kannauj, Moradabad, Pilibhit, Shahjahanpur, etc.) and adjoining states namely Madhya Pradesh (Badayun) and Rajasthan (Dholpur) in Northern India. The leprosy cases in the study were under surveillance after being treated with a full course of standard anti-leprosy multi-drug therapy, for varying periods ranging between 12-24 months. The patients were classified as tuberculoid (TT), borderlinetuberculoid (BT), mid-borderline (BB), borderlinelepromatous (BL), lepromatous (LL) and neuritic (N) leprosy according to Ridley-Jopling criteria ${ }^{[5]}$. Further, TT, BT and N leprosy patients were classified as paucibacillary whereas $\mathrm{BB}, \mathrm{BL}$ and LL were the multibacillary type of patients. The regularity of treatment was termed according to their attendance at the OPD (as defined by NLEP/NLCP), i.e., Regular-4 weeks or over 75\% of attendance; Regular, fairly-25-39 weeks or 46-74\% of regular attendance; Irregular-10-24\% weeks or $20-45 \%$ of regular attendance; Practically nil-below 10 weeks, or below $20 \%$ attendance; Discontinue-nil attendance ${ }^{[6]}$. In our study, patients who took total treatment for 9 to 12 months were considered as the regular patients and those who did not complete 9 months of treatment as the irregular patients. The dropouts were those who visited the Out Patient's Clinic once only.
Statistical analysis: The data were statistically analyzed by the Chi-Square test and normal t-test was applied to test the equality of proportion.

\section{RESULTS}

Table 1 shows the socio-demographic characteristics, i.e., sex, religion, residential background, (rural vs urban), occupation/profession, type of disease, status of initial infection/disease and history of earlier treatment of all the 2709 patients. Out of the 2709 patients attending the OPD, $76.5 \%$ (2075) were males whereas $23.4 \%$ (634) were females. $74.4 \%$ (2016) were hindus and $25.5 \%$ (693) were muslims. $96.8 \%$ (2623) of the leprosy patients had active disease at the time of inclusion in this study. 62.5\% (1693) had pauci-bacillary and $37.5 \%$ (1016) had multi-bacillary types of leprosy. $57.5 \%$ (1560) were treated and $42.4 \%$ (1149) were not taking any treatment at the time of inclusion in the study. Among the male patients, $44.7 \%$ (931) were regular but irregularity was observed among 23\% (477) and drop-outs among 32.1\% (667). Among the female patients, $46.5 \%$ (295) were regular but the number of irregular (171) and drop-out (168) patients was almost equal, i.e., $26 \%$ in each category. The number of drop-out patients was significantly higher $[\mathrm{Z}=2.16, \mathrm{p}=0.05]$ among males, 32.14\% (667) when compared with females, $26.50 \%$ (168). Religion was not observed to be a significant determinant in the regularity, irregularity and / or drop-out among the patients. The locality/ residential background seemed to play a key role in Clinic attendance. Patients from urban areas were less regular $38.9 \%$ (218) and the number of irregulars and drop-outs were more, i.e., $24.1 \%$ (135) and $37 \%$ (207), respectively when compared with the patients from rural areas. This was statistically a significant determinant in the clinic attendance $\left[\mathrm{X}^{2}=14.894, \mathrm{p}=0.00006\right]$. Pauci-bacillary or multi-bacillary type of leprosy did not appear to be a significant determinant in the regularity, irregularity and / or drop-out among the patients. With regard to the various professions, the number of irregulars and dropouts among patients engaged in some kind of business seemed to be more, i.e., $31.6 \%$ (12) and $34.2 \%$ (13), respectively. When compared patients with other occupations and even among housewives, the rate of irregularity and drop-outs among businessmen was significantly less $\left[\mathrm{X}^{2}=21.06, \mathrm{p}=0.015\right]$. Among the patients with active leprosy disease, $44.4 \%$ (1166) were regular, $24.3 \%$ (639) were irregular but $31.1 \%$ (818) were drop-outs. This is a matter of serious concern since these patients serve not only as a reservoir for further transmission of the infection but would also 
Am. J. Infect. Dis., 3 (1): 36-41, 2007

Table 1: The socio-demographic characteristics of the leprosy patients attending the Oupatient's clinic at Agra

\begin{tabular}{|c|c|c|c|c|c|c|}
\hline \multirow[t]{2}{*}{ Parameters } & & \multicolumn{4}{|c|}{$\begin{array}{l}\text { Patients } \\
\text { [Numbers }(\%)]\end{array}$} & \multirow[t]{2}{*}{$\begin{array}{l}\text { Statistics } \\
\mathrm{X}^{2}(\mathrm{p} \text { value })\end{array}$} \\
\hline & & Regular & Irregular & Drop-outs & Total & \\
\hline \multirow[t]{2}{*}{ Sex } & Male & $\begin{array}{l}931 \\
(44.77 \%)\end{array}$ & $\begin{array}{l}477 \\
(22.99 \%)\end{array}$ & $\begin{array}{l}667 \\
32.14 \%)\end{array}$ & 2075 & $\begin{array}{l}\mathrm{X}^{2}=8.541 \\
(\mathrm{n}=0.014)\end{array}$ \\
\hline & Female & $\begin{array}{l}295 \\
(46.53 \%)\end{array}$ & $\begin{array}{l}171 \\
(26.97 \%)\end{array}$ & $\begin{array}{l}168 \\
26.50 \%)\end{array}$ & 634 & \\
\hline \multirow[t]{2}{*}{ Religion } & Hindu & $\begin{array}{l}900 \\
(44.6 \%)\end{array}$ & $\begin{array}{l}490 \\
(24.3 \%)\end{array}$ & $\begin{array}{l}626 \\
(31.1 \%)\end{array}$ & 2016 & $\begin{array}{l}X^{2}=1.278 \\
(p=0.528)\end{array}$ \\
\hline & Muslim & $\begin{array}{l}326 \\
(47.0 \%)\end{array}$ & $\begin{array}{l}158 \\
(22.8 \%)\end{array}$ & $\begin{array}{l}209 \\
(30.2 \%)\end{array}$ & 693 & \\
\hline \multirow[t]{2}{*}{ Residential background } & Rural & $\begin{array}{l}1008 \\
(46.91 \%)\end{array}$ & $\begin{array}{l}513 \\
(23.87 \%)\end{array}$ & $\begin{array}{l}628 \\
(29.22 \%)\end{array}$ & 2149 & $\begin{array}{l}X^{2}=14.894 \\
(p=0.0006)\end{array}$ \\
\hline & Urban & $\begin{array}{l}218 \\
(38.93 \%)\end{array}$ & $\begin{array}{l}135 \\
(24.11 \%)\end{array}$ & $\begin{array}{l}207 \\
(36.96 \%)\end{array}$ & 560 & \\
\hline \multirow[t]{6}{*}{ Types of profession } & Agriculture & $\begin{array}{l}229 \\
(43.7 \%)\end{array}$ & $\begin{array}{l}123 \\
(23.5 \%)\end{array}$ & $\begin{array}{l}172 \\
(32.8 \%)\end{array}$ & 524 & $\begin{array}{l}X^{2}=21.06 \\
(p=0.015)\end{array}$ \\
\hline & Business & $\begin{array}{l}13 \\
(34.2 \%)\end{array}$ & $\begin{array}{l}12 \\
(31.6 \%)\end{array}$ & $\begin{array}{l}13 \\
(34.2 \%)\end{array}$ & 38 & \\
\hline & Service & $\begin{array}{l}207 \\
(40.4 \%)\end{array}$ & $\begin{array}{l}125 \\
(24.4 \%)\end{array}$ & $\begin{array}{l}180 \\
(35.2 \%)\end{array}$ & 512 & \\
\hline & Others & $\begin{array}{l}442 \\
(48.9 \%)\end{array}$ & $\begin{array}{l}192 \\
(21.3 \%)\end{array}$ & $\begin{array}{l}269 \\
(29.8 \%)\end{array}$ & 903 & \\
\hline & Child & $\begin{array}{l}40 \\
(40.8 \%)\end{array}$ & $\begin{array}{l}25 \\
(25.5 \%)\end{array}$ & $\begin{array}{l}33 \\
(33.7 \%)\end{array}$ & 98 & \\
\hline & Housewife & $\begin{array}{l}295 \\
(46.5 \%)\end{array}$ & $\begin{array}{l}171 \\
(27.0 \%)\end{array}$ & $\begin{array}{l}168 \\
(26.5 \%)\end{array}$ & 634 & \\
\hline \multirow[t]{2}{*}{ Types of disease } & Pauci - bacillary & $\begin{array}{l}767 \\
(45.3 \%)\end{array}$ & $\begin{array}{l}411 \\
(24.3 \%)\end{array}$ & $\begin{array}{l}515 \\
(30.4 \%)\end{array}$ & 1693 & $\begin{array}{l}X^{2}=0.49 \\
(p=0.786)\end{array}$ \\
\hline & Multi - bacillary & $\begin{array}{l}459 \\
(45.2 \%)\end{array}$ & $\begin{array}{l}237 \\
(23.3 \%)\end{array}$ & $\begin{array}{l}320 \\
(31.5 \%)\end{array}$ & 1016 & \\
\hline \multirow[t]{2}{*}{$\begin{array}{ll}\text { Clinical disease/ } \\
\text { Bacterial Index }\end{array}$} & Active & $\begin{array}{l}1166 \\
(44.45 \%)\end{array}$ & $\begin{array}{l}639 \\
(24.36 \%)\end{array}$ & $\begin{array}{l}818 \\
(31.19 \%)\end{array}$ & 2623 & $\mathrm{X}^{2}=22.035$ \\
\hline & Inactive & $\begin{array}{l}60 \\
(69.77 \%)\end{array}$ & $\begin{array}{l}9 \\
(10.47 \%)\end{array}$ & $\begin{array}{l}17 \\
(19.76 \%)\end{array}$ & 86 & $(p=0.00001)$ \\
\hline \multirow[t]{3}{*}{ Treatment status } & Treated & $\begin{array}{l}708 \\
(45.5 \%)\end{array}$ & $\begin{array}{l}351 \\
(22.5 \%)\end{array}$ & $\begin{array}{l}501 \\
(32.1 \%)\end{array}$ & 1560 & $\begin{array}{l}X^{2}=5.107 \\
(p=0.078)\end{array}$ \\
\hline & Untreated & $\begin{array}{l}518 \\
(45.1 \%)\end{array}$ & $\begin{array}{l}297 \\
(25.8 \%)\end{array}$ & $\begin{array}{l}334 \\
(29.1 \%)\end{array}$ & 1149 & \\
\hline & Total & $\begin{array}{l}1226 \\
(45.26 \%)\end{array}$ & $\begin{array}{l}648 \\
(23.92 \%)\end{array}$ & $\begin{array}{l}835 \\
(30.82 \%)\end{array}$ & 2709 & \\
\hline
\end{tabular}

eventually develop complications. Among the patients in whom the disease had become inactive as evident from the bacterial index, $69.7 \%$ (60) were regular, the irregularity and drop-out rate was $10.4 \%$ (9) and $19.7 \%$ (17), respectively. This appeared to be a statistically significant determinant for clinic attendance $\left[\mathrm{X}^{2}=5.107\right.$, $\mathrm{p}=0.078]$. Thus, regular clinic attendance had an impact in rendering the active state of the disease to an inactive status. In all, 1226 (45.26\%) patients were found to be regular in clinic attendance but $648(23.92 \%)$ patients were irregular and $835(30.83 \%)$ patients were dropouts.

\section{DISCUSSION}

Leprosy is a major public health problem in most of the developing world and is often found in conditions connected with poverty, overcrowding, poor sanitation and insufficient nutrition ${ }^{[7,8]}$. According to current WHO data, the current global prevalence rate is around 1.4 cases per 10,000 people. Around 5,00,000 new cases of leprosy are registered each year. India alone has about 5,00,000 infected people, which represents $63 \%$ of the global occurrences and $87 \%$ of the cases for the region ${ }^{[9]}$. Leprosy, a chronic infectious disease that, if left untreated, can cause debilitating deformities and slowly progress throughout one's life. It is characterized by peripheral nerve damage, cutaneous lesions and a wide range of clinical manifestations. In order to contract the disease, one has to live in close contact with an infected individual for a prolonged amount of time ${ }^{[10,11]}$. These physical effects paired with the social stigma of being infected with this dreaded disease, often lead to those affected being afraid to come forward to seek treatment In the early stages of 
Am. J. Infect. Dis., 3 (1): 36-41, 2007

Table 2: The comparative studies and the various reasons for non-compliance of Leprosy patients by other authors

\begin{tabular}{|c|c|c|c|c|c|}
\hline Authors & $\begin{array}{l}\text { Place of } \\
\text { study }\end{array}$ & $\begin{array}{l}\text { Year of } \\
\text { study }\end{array}$ & $\begin{array}{l}\text { Total no. } \\
\text { of } \\
\text { Leprosy } \\
\text { Patients }\end{array}$ & $\begin{array}{l}\text { Irregular } \\
\text { Patients }(\%)\end{array}$ & Reasons for non-compliance \\
\hline $\begin{array}{l}\text { Bhagoliwal et } \\
a l^{27}\end{array}$ & Kanpur & 1979 & 252 & $\begin{array}{l}79(31.23 \%)- \\
\text { regular } \\
174(68.77 \%)- \\
\text { defaulter }\end{array}$ & $\begin{array}{l}\text { Carelessness, illiteracy, ignorance, prolonged treatment period, } \\
\text { social stigma, religious ceremonies, false feeling of complete } \\
\text { recovery, failure to accept the diagnosis. }\end{array}$ \\
\hline $\begin{array}{l}\text { Ekambram et } \\
a^{28}\end{array}$ & $\begin{array}{l}\text { Tamil } \\
\text { Nadu }\end{array}$ & 1974 & - & - & $\begin{array}{l}\text { rich and prominent persons of the totality are not willing to come } \\
\text { to the public clinic. } \\
\text { Daily labour, minimal lesions, dis-belief,dis-satisfaction, with } \\
\text { prolonged treatment, social stigma, occasional absence due to } \\
\text { religious functions. }\end{array}$ \\
\hline $\mathrm{K}_{29}$ Kannan et al & $\begin{array}{l}\text { Tamil } \\
\text { Nadu }\end{array}$ & 1992 & 500 & $\begin{array}{l}289(57.8 \%)- \\
\text { regular } \\
211(42.2 \%)- \\
\text { irregular }\end{array}$ & $\begin{array}{l}\text { [rural patients were more regular }(61.2 \%) \text { than their urban } \\
\text { counterpart }(54.4 \%) \text { ]. }\end{array}$ \\
\hline Nair et al ${ }^{30}$ & $\begin{array}{l}\text { South } \\
\text { India }\end{array}$ & $\begin{array}{l}1955- \\
75\end{array}$ & 10,272 & $42.75 \%$ & - \\
\hline Nigam et al 31 & Jhansi & 1979 & 1970 & $\begin{array}{l}\text { - irregular } \\
52 \% \text { - regular }\end{array}$ & $\begin{array}{l}\text { Economic reasons : } 29.5 \% \text {, } \\
\text { No time to attend clinic }-12.5 \% \\
\text { Ignorance }-22.9 \% \\
\text { Social stigma }-1.2 \% \\
\text { Reaction in leprosy }-12.5 \%\end{array}$ \\
\hline Nwosu et al ${ }^{32}$ & Nigeria & 2002 & 53 & $\begin{array}{l}39.6 \% \text { - irregular } \\
7.5 \% \text { - defaulter }\end{array}$ & $\begin{array}{l}\text { Attendance at meetings, work at home, fear/shame/indignation, no } \\
\text { confidence in treatment. }\end{array}$ \\
\hline${ }_{33}^{\text {Raghavia et al }}$ & $\begin{array}{l}\text { Tamil } \\
\text { Nadu }\end{array}$ & 1987 & 3382 & 150 & $\begin{array}{l}\text { irregulars : backward (54\%), scheduled castes }(35 \%) \text {, more }(32 \%) \\
\text { in the initial phase of the disease, illiterate group }(61 \%) \text {. work }\end{array}$ \\
\hline Shesh Pal et al $_{34}$ & Agra & 1985 & 195 & $\begin{array}{l}71(36.41 / \%)- \\
\text { irregular }\end{array}$ & $\begin{array}{l}\text { Miscellaneous : extremes of season, harvest, festivals - } 18.3 \% \text {, } \\
\text { Practical : long distances, family problem, poverty, illnesses - } \\
63.4 \% \\
\text { Therapeutic : no benefit, loss of index card, no attention to other } \\
\text { complaints }-2.8 \% \text {; Lack of awareness : apathy, sympatomatic, } \\
\text { unaware - } 15.5 \%\end{array}$ \\
\hline Vellut et al ${ }^{35}$ & $\begin{array}{l}\text { Southern } \\
\text { India }\end{array}$ & & 1200 & 120 & Anxiety for loss of income \\
\hline $\begin{array}{l}\text { Present Study, } \\
\text { Yadav et al }\end{array}$ & Agra & 2005 & 2709 & $\begin{array}{l}\text { Regular - } \\
(45.26 \%) \\
\text { Irregular - } 648 \\
(23.92 \%) \\
\text { Drop-Outs - } 835 \\
(30.83 \%) \\
\end{array}$ & $\begin{array}{l}\text { Irregularity and drop-out patients are more among Males, patients } \\
\text { from urban areas and those with active disease. }\end{array}$ \\
\hline
\end{tabular}

the disease ${ }^{[12]}$. The emergence of drug-resistant Mycobacterium leprae, as well as increased numbers of cases worldwide, have led to global concern about this disease $^{[13]}$. Early recognition and treatment limits damage by the disease, renders the person noninfectious and allows for a normal lifestyle ${ }^{[14,15]}$. Although years are required for the elimination of M.leprae from the skin, most bacilli are dead within 3-6 months of the initiation of effective therapy. The shedding of viable M.leprae in nasal secretions and bacteremia also cease within 3-6 months. Therefore, except for the first few months of treatment, outpatient management is adequate for the vast majority of patients ${ }^{[16,17]}$. To minimize the possibility of relapse, therapy should be continued until all M.leprae have disappeared from the skin, a matter of at least 5 years in lepromatous patients ${ }^{[18]}$. However, lifelong chemotherapy is indicated in patients who fail to recover lepromin reactivity because persisting mycobacteria predispose these patients to relapse. Patients with tuberculoid leprosy should be treated for 1-2 years beyond the resolution of apparent lesions ${ }^{[19]}$. Sub-clinical disease is common in endemic areas and the infection progresses to clinical disease in only a select few. Patients with leprosy can be treated on an outpatient basis but some may need hospitalization for acute complications. Most patients first need an explanation of the diagnosis and prognosis, their fears should be addressed because of the cultural stigma associated with leprosy. They may need psychological counseling because they may have difficulty in coming to terms with the disease or in feeling rejected by 
society. The management of leprosy includes chemotherapy to stop the infection, treatment to minimize potential physical deformities and physical, social and psychological rehabilitation. Potential deformities can be prevented by educating patients about how to deal with existing nerve damage and by treating any sequelae of this damage. Close follow-up is important to ensure patient compliance ${ }^{[20-23]}$. Monitoring for drug resistance and adverse reactions to medications is essential ${ }^{[24]}$. Table 2 depicts the comparative studies of irregularity among leprosy patients by several authors in India and abroad. Although these periodic studies indicated that the reasons for irregularity are different in different regions $^{[25-35]}$, India continues to be one of the endemic countries with new case detection rates ranging from $0.5 \%$ to $20 \%$. New case detection rates have decreased and this could be attributed to the better control due to multi-drug therapy and decreased transmission of M.leprae, with new cases dominated by a long period of incubation, in the lepromatous leprosy cases ${ }^{[36]}$. There is an urgent need to perform population based surveys of leprosy prevalence in India to assess the true extent of the problem.

Our study indicated that default and irregular clinic attendance by patients with leprosy are numerically large and may compound the problems of National Leprosy Elimination programmes and thus negate the realization of the global goal of intercepting leprosy transmission. Regularity in Clinic attendance and strict adherence to treatment regimens could have a significant effect on the epidemiology of leprosy.

We, therefore, feel that supervising the treatment of patients with active leprosy disease, irrespective of the paucibacillary or multi-bacillary status, would go a long way in reducing the irregularity in clinic attendance which, in turn, would help in early detection of new cases. An early and regular treatment, if initiated, would help in further deterioration and complications resulting from anaesthesia and associated morbidity due to nerve involvement in the infection(s) as well as further transmission of the infection. There is a need, therefore, to support an approach of targetted screening, integrate leprosy testing, counseling, referral services and direct supervision of treatment into the existing system for leprosy prevention and /or treatment services.

\section{ACKNOWLEDGEMENTS}

The authors thank Dr.V.M.Katoch, Director for encouragement and the entire staff of OPD of the Institute for their assistance in the study.

\section{REFERENCES}

1. http: //www. Who india. Org /EN /Section 3/ Section 122_652. htm.

2. WHO, 2005.Leprosy in the $21^{\text {st }}$ century.

3. Global situation of leprosy control at the beginning of the 21 st century. Report of the international leprosy association technical forum. 2002, Lepr. Rev., 73: S13-16.

4. Br. Suresh. National Leprosy Eradication Programme (NLEP).

5. Ridley, D.S. and W.H. Jopling, 1966. Classification of leprosy according to immunity: A five group system. Int. J. Lep., 34: 255-267.

6. Nair, N.G.K., S. RadhaKrishna, M. Christian, R. Ramakrishnan and P.G. Gopi, 1985. A 20 year study of the leprosy control programme at the Hemerjckx leprosy center in Polambakkam in South India. Ind. J. Lepr., 57: 562-574.

7. Lockwood, D.N.J., 2001. Leprosy and poverty.

8. Lockwood, D.N.J., 2002. Leprosy. Clin. Evid., 8: 709-720.

9. Noordeen, S.K., L. Lopez Bravo and T.K. Sudaresan, 1992. Estimated number of leprosy cases in the world. Ind. J. Lepr., 64: 521-527.

10. Lepra. Health in Action. What is leprosy?

11. Core Programme Clusters. April, 2005. (Communicable Diseases and Disease Surveillance) Leprosy.

12. Kasturi, G., 1973. A study of attitude of leprosy patients; their disease, treatment and their status in society. Lepr. India, 54: 239-249.

13. A guide to eliminating leprosy as a public health problem, 1995. 1st edition, WHO/LEP/95.1, WHO, Geneva.

14. Chemotherapy of leprosy for control programsreport of WHO study. WHO.

15. WHO model prescribing information-drug used in leprosy, 1998. WHO/DMP/DSI/98. 1, WHO, Geneva.

16. Noordeen, S.K., 1971. Domiciliary treatment of leprosy. Lepr. India, 43: 11-13.

17. Koticha, K.K., 1973. Regular treatment is essential for controlling leprosy with dapsone. Lepr. India; 45: 75-77.

18. Koticha, K.K. and M.P.R. Ravendran, 1979. Treatment to defaulters in leprosy: A retrospective study 42,000 cases. Int. J. Lepr., 47: 50-55.

19. Jesudasan, K., D. Bradley and M. Christian, 1985. Are defaulters with paucibacillary leprosy a problem? Ind. J. Lepr., 57: 354-359.

20. Kumar, A., 1984. Treatment compliance by leprosy out-patients and its monitoring under field conditions. Ind. J. Lepr., 56: 313-318. 
21. Low, S.J.M., J.M.H. Pearson, 1974. Do Leprosy patients take dapsone regularly ? Lepr. Rev., 45: 218.

22. Nair, S.S. and R. Ganapati, 1977. Regularity of dapsone intake by leprosy patients attending urban treatment center. Lepr. India, 49: 207-215.

23. Ellard, G.A., T.P. Gammon and J.M. Harris, 1974. The application of urine test to monitor the regularity of dapsone self-administration. Lepr. Rev., 45: 224-232.

24. Gidoh, M., S. Tsutsumi, T. Funazu, S. Koide, and S. Narita, 1997. On characteristic antiinflammatory effects of several anti-leprosy drugs. Jap. J. Lepr., 48: 7-18.

25. Ramanaiah, T.B.B.S.V., P. Jaysingh and S.D. Fernandes, 1986. Non-compliance to treatment among leprosy patients. Lepr. India, 58: 96-106.

26. Goyal, P.K., 1979. Study of defaulters in treatment of leprosy. Lepr. India, 48(Supp.): 848-850.

27. Bhagoliwal, A., J.Chandra, J., Mishra, R.S., 1979. Some observations on default among leprosy patients. Lepr. India ; 51 : 96-102.

28. Ekambaram, V., 1974. Absenteeism for treatment, their causes and suggested remedial measures. Lepr. India, 46: 46-48.

29. Kannan, N. and M. Sivaram, 1992. Variables influencing regularity of leprosy patients in attending treatment clinics. Ind. J. Lep., 64: 508511.
30. Nair, S.S., 1978. Irregularity of dapsone intake by infectious leprosy patients attending an urban treatment center. Lepr. India, 50: 50-53.

31. Nigam, P., M.I.A. Siddique, R.N. Pandey, K.N. Awasthi and R.N. Srivastava, 1979. Irregularity of treatment in leprosy patients, its magnitude and causes. Lepr. India, 51: 521-532.

32. Nwosu, M.C. and S.N.N. Nwosu, 2002. Leprosy control in the post leprosaria abolition years in Nigeria: Reasons for default and irregular attendance at treatment centers. West Afr. J. Med., 21: 177.

33. Raghavia, M., R.D. Bansal, D.K. Srinivasa, M.B. Soudarssanane and G. Ramana, 1987. Absenteeism in leprosy patients in a rural area in Tamil Nadu. Ind. J. Lepr., 59: 322-329.

34. Pal, S., U. Ramanathan and G. Ramu, 1985. A study of the cause of irregularity of patients attending the out patient department of C.J.I.L., Agra. Ind. J. Lep., 57: 607-612.

35. Vellut, C., D. Van der Veid, C. Supplisson and J.M. Decazes, 1982. Absenteeism during treatment for leprosy. Analysis of causes as apparent from a survey in southern India. Acta Leprol., 89: 27-38.

36. Meima, A., M.D. Gupte, G.J. vanOortmarssen and J.D.D. Habbema, 1997. Trends in Leprosy case detection rates. Int. J. Lep., 65: 305-319. 